\section{REFERENCES AND NOTES}

1. Adam, P. A. J., Kekomaki, M., Rahiala, E. D., and Schwartz, A. L. Autoregulation of glucose production by isolated perfused human liver. Pediat. Res., 6: 396 (1972).

2. Adam, P. A. J., Kornhauser, D., Link, D., and Schwartz, R.: Relationship of insulin secretion rate to blood of glucose concentration in newborn and adult dogs. Biol. Neonate., 14: 194 (1969).

3. Ballard, F. J., In: U. Stave: Physiology of the Perinatal Period, Vol. 1, Chap. 13 pp. 417-440, (Appleton-Century-Crofts, New York, 1970).

4. Bowie, M. D., Mulligan, P. B., and Schwartz, R.: Intravenous glucose tolerance in the normal newborn infant: The effect of double dose of glucose and insulin. Pediatrics, 31: $590-596$ (1963)

5. Buschiazzo, H., Exton, J. H., and Park, C. R.: Effects of glucose on glycogen synthetase, phosphorylase, and glycogen deposition in the perfused rat liver. Proc. Nat. Acad. Sci. U. S. A., 65: 383 (1970).

6. Cornblath, M., and Schwartz, R.: Disorders of Carbohydrate Metabolism in Infancy, pp. 57-81, (W. B. Saunders Co., Philadelphia, 1966).

7. Curnow, R. T., Rayfield, E. J., George, D. T., Zenser, T. V., and De Rubertis, F.: Control of hepatic glycogen metabolism in the rhesus monkey; the effect of glucose, insulin, and glucagon administration. Amer. J. Physiol., 228: 80 (1974).

8. Devos, P., and Hers, H.-G.: Glycogen metabolism in the liver of the foetal rat. Biochem. J., 140: 331 (1974).

9. Eisen, H. J., Glinsmann, W. H., and Sherline, P.: Effect of insulin on glycogen synthesis in fetal rat liver in organ culture. Endocrinology, 92: 584 (1973).

10. Eisen, H. J., Goldfine, I. D., and Glinsmann, W. H.: Regulation of hepatic glycogen synthesis during fetal development: Roles of hydrocortisone, insulin, and insulin receptor. Proc. Nat. Acad. Sci. U. S. A., 70: 3454 (1973).

11. Exton, J. H., Lewis, S. B., Ho, R. J., and Park, C. R.: The role of cyclic AMP in the control of hepatic glucose production by glucagon and insulin. Advan. Cyclic Nucl. Res., 1: 91 (1972).

12. Fleishman, A. R., Lerman, S., Oaks, G. K., Epstein, M. F., Chez, R. A., and Mintz, D. H.: Perinatal primate parathyroid hormone metabolism. Biol. Neonate, 27: 40 (1975).

13. Genser, G., Lundquist, I., and Nilsson, E.: Glycogenolytic activity in the liver of the human fetus. Biol. Neonate, 19: 1 (1971)

14. Gilboe, D. P., and Nuttal F. Q.: The regulation of liver glycogen synthetase by ATP and glucose. Biochem. Biophys. Res. Commun., J3: 164 (1973).

15. Gladtke, E., Dost, F. H., and van Hattingberg, M.: Glucose imsatz bei Neugeborenen. Deut. Med. Wschr., 93: 684 (1968).

16. Glinsmann, W. H., Hern, E. P., and Lynch, A.: Intrinsic regulation of glucose output by rat liver. Amer. J. Physiol., 216: 698 (1969).
17. Glinsmann, W. H., and Mortimore, G. E.: Influence of glucagon and 3',5'-AMP on insulin responsiveness of the perfused rat liver. Amer. J. Physiol., 215: 553 (1968).

18. Glinsmann, W., Pauk, G., and Hern, E.: Control of rat liver glycogen synthetase and phosphorylase activities by glucose. Biochem. Biophys. Res. Commun., 39: 774 (1970)

19. Hers, H.-G., Stahlmans, W., DeWolf, H., Lalous, M., and Hue, L.: The control of glycogen metabolism in liver. In: E. H. Fisher: Metabolic Interconversion of Enzymes, pp. 89-98, Springer-Verlag, Berlin, (1973).

20. King, K. C., Adam, P. A. J., Clemente, G. A., and Schwartz, R.: Infants of diabetic mothers: Attenuated glucose uptake without hyperinsulinemia during continuous glucose infusion. Pediatrics, 44: 381 (1969).

21. McCann, M. L., Chen, C. H., Katigbak, E. B., Kotchen, J. M., Likly, B. F., and Schwartz, R.: Effects of fructose on hypoglycosemia in infants of diabetic mothers. New Engl. J. Med., 275: 1 (1966).

22. Mintz, D. H., Chez, R. A., and Hutchinson, D. L.: Subhuman primate pregnancy; complications by streptozotocin-induced diabetes mellitus. J. Clin. Invest., 51: 837 (1972).

23. Mortimore, G. E., King, E., Jr., Mondon, C. E., and Glinsmann, W. H.: Effects of insulin on net carbohydrate alterations in perfused rat liver. Amer. J. Physiol., 212: 179 (1967).

24. Pennoyer, M. M., and Hartman, A. F.: Management of infants born of diabetic mothers. Postgrad. Med., 18: 199 (1955).

25. Reardon, H. S.: In: Infants of Diabetic Mothers: Report of the thirty-first Ross Conference on Pediatric Research, pp. 72-77, (Ross Laboratories, Columbus, Ohio, 1958).

26. Schwartz, A. L., Ph.D. thesis. Hormonal regulation of glucose production in human fetal liver (Case Western Reserve University, 1974).

27. Schwartz, A. L., and Rall, T. W.: Hormonal regulation of glycogen metabolism in neonatal rat liver. Biochem. J., /34: 985 (1973).

28. Shelley, H. J., and Neligan, G. A.: Neonatal hypoglycemia. Brit. Med. Bull., 22: 34 (1966).

29. Sherline, P., Eisen, H., and Glinsmann, W.: Acute hormonal regulation of cyclic AMP content and glycogen phosphorylase activity in fetal liver in organ culture. Endocrinology, 94: 935 (1974).

30. Varma, S., Nickerson, H., Cowen, J. S., and Hetenyi, G., Jr.: Homeostatic responses to glucose loading in newborn and young dogs. Metabolism, 22: 1367 (1973).

31. Zieve, F. J., and Glinsmann, W. H.: Activation of glycogen synthetase and inactivation of phosphorylase kinase by the same phosphoprotein phosphatase. Biochem. Biophys. Res. Commun., 50: 872 (1973).

32. Requests for reprints should be addressed to: W. H. Glinsmann, National Institutes of Health, Bldg. 6, Rm. 314, Bethesda, Md. 20014 (USA)

33. Accepted for publication, March 26, 1975.

Printed in U.S.A.

Pediat. Res. 9: 604-609 (1975)

Capillary blood

hypothyroidism, congenital thyroxine $\left(\mathrm{T}_{4}\right)$

\title{
Thyroxine $\left(\mathrm{T}_{4}\right)$ Immunoassay Using Filter Paper Blood Samples for Screening of Neonates for Hypothyroidism
}

\author{
P. REED LARSEN (18) AND KATHY BROSKIN
}

Division of Endocrinology and Metabolism, Department of Medicine, University of Pittsburgh School of Medicine, Pittsburgh, Pennsylvania, USA

Extract

A rapid, sensititive radioimmunoassay for thyroxine $\left(T_{4}\right)$ is described which requires a specimen of dried blood on filter paper. One milliliter of glycine-acetate buffer containing anti- $\mathrm{T}_{4}$ antibody, tracer $T_{4}$, and sodium salicylate is added to a tube containing a $1 / 8$-inch dot of the filter paper specimen. After incubation overnight, bound and free hormone are separated by addition of dextran-coated charcoal. Quantitation is obtained using a standard curve prepared from dots of dried blood samples with known $T_{4}$ content. The dot remains in the solution throughout the procedure. Recovery of $\mathrm{T}_{4}$ is $95 \%$ and intra- and interassay coefficients of variation are both less than $10 \%$. The mean $T_{4}$ content of 983 samples from 3-day-old infants was $189 \pm 48 \mathrm{pg} T_{4} /$ dot (mean SD). This corresponds to the $T_{4}$ in $1.5 \mu \mathrm{l}$ plasma, and thus the estimated plasma $T_{4}$ in these infants is $12.6 \pm 3.2 \mu \mathrm{g} \mathrm{T}_{4} / 100$ ml. Nine neonates had repeated samples in which the $T_{4}$ content was lower than 2 SD below the mean. All of these infants had normal cord thyroid-stimulating hormone (TSH) concentrations and thus presumably do not have primary hypothyroidism. The method 
should be useful for screening neonates (and older infants), since it can be adapted for use with the punch-index machine for automated processing, no prior extraction of $\mathrm{T}_{4}$ from the dot is required before quantitation, and the small size of the sample allows repeated tests of suspicious results.

\section{Speculation}

A method for measuring $T_{4}$ in dried blood collected on filter paper is presented which should be useful in large scale screening programs for the detection of congenital hypothyroidism.

The recent development of immunoassays for measurement of $\mathrm{T}_{4}$ in small quantites of serum has led to the application of these techniques to neonatal screening for hypothyroidism. A frequency of 1 in 8,500 has been suggested for this condition from the recent experience in Pittsburgh reported by Klein et al. (4) and a frequency of approximately 1 in 10,000 from the data of Dussault et al. (2) in the Quebec population. This relatively high incidence, similar to that reported for phenylketonuria (PKU), would appear to justify intensive efforts at early recognition of the disease so that treatment may be instituted to prevent or ameliorate the mental retardation which is part of the natural course of the untreated disease. The recent reports of Dussault et al. $(2,3)$ and O'Donnell et al. (6) have already demonstrated the feasibility of using a measurement of $\mathrm{T}_{4}$ in capillary blood samples collected on filter paper to screen for hypothyroidism. The present report deals primarily with the methodology of a $\mathrm{T}_{4}$ assay for screening purposes which may have certain technical advantages over those reported previously.

\section{METHODS AND MATERIALS}

\section{SOURCE AND TYPE OF SPECIMEN ANALYZED}

With the cooperation of the Magee-Womens Hospital in Pittsburgh, Pennsylvania and after informed consent from each mother, three additional $1 / 2$-inch filter paper circles were filled with blood from each infant at the time of heel puncture for PKU testing. The samples were usually collected on the third day of life in full term infants but at various ages in premature infants. The filter papers were received in our laboratory with 1-3 days of obtaining the blood samples and were stored either at room temperature or more recently, at $4^{\circ}$.

\section{PROCEDURE FOR ELUTING AND MEASURING T، IN DRIED BLOOD} SAMPLES

After considerable experimentation, the following procedure was adopted. Some of the considerations used in arriving at this method are discussed in greater detail under Results. The basic principles of the immunoassay are those described previously for assay of $T_{4}$ in human serum (5).

\section{SOLUTIONS}

Glycine-Acetate Buffer. Glycine-acetate buffer (GAB), pH 8.6, was comprised of $0.2 \mathrm{M}$ glycine, $0.13 \mathrm{M}$ sodium acetate.

Antibody Solution. Antibody solution was comprised of GAB containing anti- $T_{4}$ antibody (obtained from rabbits immunized with bovine thyroglobulin as described previously (5) at a dilution of $1: 15,000,5 \mathrm{mg} / \mathrm{ml}$ of sodium salicylate (to block $\mathrm{T}_{4}$ thyroxinebinding globulin (TBG) binding, and $4,000-8,000 \mathrm{cpm} / \mathrm{ml}$ (but $<75 \mathrm{pg}$ ) of $\left[{ }^{125} \mathrm{I}^{1} \mathrm{~T}_{4}(7)\right.$.

Preparation of Standard Dots. In this procedure thyroxine (free acid (8)) was dissolved in $0.04 \mathrm{~N} \mathrm{NaOH}$ at a concentration of 32 $\mu \mathrm{g} / \mathrm{ml}$. The concentration was verified by spectrophotometry using the molar extinction coefficient as described (5). Heparinized blood from a patient with myxedema was enriched with $\mathrm{T}_{4}$ to yield the following concentrations of exogenous $\mathrm{T}_{4}: 0,2,4,6,8$, and 10 $\mu \mathrm{g} / 100 \mathrm{ml}$ whole blood. After mixing well by inversion, aliquots of each of these standards and the unenriched blood were spotted on filter paper identical with that used in collecting the neonatal specimens. An aliquot of each sample was then centrifuged and the $\mathrm{T}_{4}$ concentration was determined in the plasma supernatant by immunoassay as described previously (5). In addition, aliquots of the standards were en riched with $\left[{ }^{125} \mathrm{I}\right] \mathrm{T}_{4}$ and placed on filter paper to allow determination of the quantities of $\mathrm{T}_{4}$ eluted.

Charcoal Solution. The following reagents were added to 1 liter of distilled deionized water; $7.65 \mathrm{~g}$ sodium chloride, $12.5 \mathrm{~g}$ decolorizing neutral carbon (9) and $1.25 \mathrm{~g}$ T80 dextran (10). This solution was mixed well and stored at $4^{\circ}$. Dextran-coated charcoal solution for separation of bound and free $\mathrm{T}_{4}$ was prepared by appropiate dilution of this solution. The optimal dilution is determined experimentally from time to time since different results are obtained with different lots of charcoal. Currently, $200 \mathrm{ml}$ dextran-charcoal solution described above is mixed with $150 \mathrm{GAB}$.

\section{PROCEDURE FOR ASSAY}

A standard $1 / 8$-inch paper punch was used to punch dots of both standard and unknowns (in duplicate) into clean polystyrene tubes, $16 \times 125 \mathrm{~mm}$ (11). Two additional spots from one of the standards were also punched for use in tubes to which $G A B$ with only salicylate and tracer $\mathrm{T}_{4}$ added to serve as a control for nonspecific binding. With a Micro-Medic automatic dispensing pipetter (12), 1 ml diluent containing antibody, tracer, and sodium salicylate was added to each tube. The tubes were then vortexed briefly and it was ascertained that the paper dot remained in the solution. The tubes were stored overnight at $4^{\circ}$ and the total number of counts in each tube was determined by counting 10 tubes at random. Separation of bound and free $\left[{ }^{125} \mathrm{I}\right] \mathrm{T}_{4}$ was obtained by adding $1 \mathrm{ml}$ diluted, cold dextran-charcoal solution, vortexing briefly and allowing the tubes to remain at $4^{\circ}$ in an ice-bath for $45 \mathrm{~min}$ after addition of the charcoal. In practice, dextran-coated charcoal was added to tubes in groups of 80 (the limit of the centrifuge) using a Bio-Pet (13). The addition of the charcoal solution should take no longer than 5 $\min$. The tubes were then centrifuged at $4^{\circ}$ for $15 \mathrm{~min}$ at $2,000 \mathrm{rpm}$ in a Sorvall RC-3 refrigerated centrifuge. The supernatant was decanted and a $1-\mathrm{ml}$ aliquot transferred to a polystyrene tube, $16 \times$ $125 \mathrm{~mm}$ and counted in an automatic $\gamma$ counter.

Quantitation was obtained from the binding-displacement curve constructed using the standard dots.

\section{RESULTS}

\section{RATIONALE FOR USE OF 1/8-INCH DOT}

In Figure 1 are shown samples of specimens received in our laboratory. It has been our experience that the $1 / 2$-inch circles preprinted on the filter paper are often incompletely filled with blood. For this reason, we elected to use smaller dots and, at first, adapted the method for the $1 / 4$-inch dot shown in the middle of the upper row. It became apparent subsequently that even greater sensitivity was both possible and desirable and a method was developed which required only a $1 / 8$-inch dot. Figure 1 shows that even small quantities of blood such as those seen in the specimens on the bottom row still provide adequate samples for at least two, and sometimes three, specimens. Other advantages were found using the smaller dots. First, whereas recovery from the $1 / 2$-inch spot containing about $38 \mu \mathrm{l}$ blood was only $77 \%$, approximately $95 \%$ of the $\mathrm{T}_{4}$ can be eluted from a $1 / 8$-inch dot. It was also found that it is not necessary to remove the $1 / 8$-inch dot from the reaction mixture during the process of the assay and thus a timeconsuming extraction step is avoided.

In Table 1 are depicted the quantities of blood contained on the $1 / 8$-inch dots using four samples of normal adult blood and five samples of cord blood, both spotted after heparinization. In the normal adult human samples, $2.83 \mu \mathrm{l}$ whole blood is contained in the dot. The amount of whole blood was determined by prelabeling the blood with $\left.{ }^{\left[{ }^{125}\right.} \mathrm{I}\right] \mathrm{T}_{4}$, counting an appropriate aliquot and comparing these counts with those in a $1 / 8$-inch dot. The results shown are the means of quintuplicate samples. Since the distribu- 
tion of $T_{4}$ is limited to plasma, the results reflect the quantity of plasma contained in the $1 / 8$-inch dot. We have assumed that there is no segregation of the blood cells from the plasma for the purpose of these calculations. In the third column are presented the quantities of $\left.{ }^{125} \mathrm{I}\right] \mathrm{T}^{4}$ in microliter equivalents found in the supernatant after overnight incubation under the conditions described under Methods. In normal human serum this amounts to quantities of $T_{4}$ equivalent to that found in $1.46 \mu \mathrm{l}$ plasma and represents extraction of $94.9 \%$ of the $\left[{ }^{125} \mathrm{I}\right] \mathrm{T}_{4}$ present in the dot. In the lower half of Table 1 are presented data obtained from cord blood. Cord blood has a higher hematocrit than that found in adult blood and there appears to be a rough correlation between the hematocrit and the amount of blood found on the 1/8-inch dot (again determined as the quantity of $\left[{ }^{125} \mathrm{I}^{1} \mathrm{~T}_{4}\right.$ per dot). Thus, while there is $2.83 \mu \mathrm{l}$ whole blood/dot in the four samples of normal blood with a mean hematocrit of $45 \%$, there are $3.45 \mu \mathrm{l}$ whole blood/dot in the five samples of cord blood. This difference is

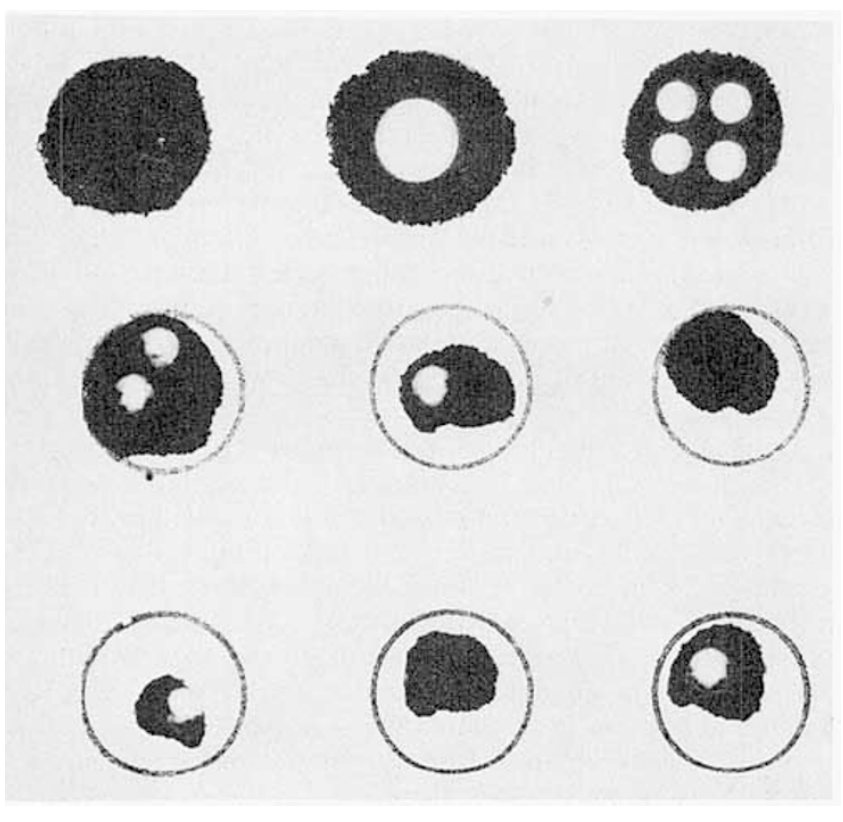

Fig. 1. Representative samples of filter paper containing dried capillary blood specimens received in our laboratory. The printed circle seen in the middle and bottom rows is $1 / 2$ inch in diameter. The hole in the middle circle of the top row is $1 / 4$ inch diameter while the remainder are $1 / 8$-inch dots. significant whereas the quantity of plasma per dot is not different. This suggests that it is the quantity of plasma which determines the area of filter paper occupied by the blood rather than the total volume of blood. In any case, the extraction of $\left[{ }^{125} I\right] T_{4}$ is approximately $95 \%$, indicating that the higher quantities of TBG present in cord blood do not interfere with elution of $\mathrm{T}_{4}$ from the paper.

A major factor which interferes with elution of $\mathrm{T}_{4}$ is preheating of the sample. In samples autoclaved for $5 \mathrm{~min}$, a procedure used locally before PKU testing, only $5-10 \%$ of $\mathrm{T}_{4}$ is eluted from the filter paper. However, at room temperature or at $4^{\circ}$, we have not observed any decrease in the percent of $\mathrm{T}_{4}$ eluted from a $1 / 8$-inch dot over a period of as long as 3 months and after 5 months at room temperature the recovery was $84.9 \%$.

\section{STANDARD CURVE OBTAINED USING 1/8-INCH DOTS}

In Table 2 are presented data obtained from the standard curve prepared as described under Methods. The antibody was diluted to allow more precise estimates of $\mathrm{T}_{4}$ values in the lower portion of the normal range than at higher levels. Thus, the displacement curve slope decreased at higher $\mathrm{T}_{4}$ levels. The plasma $\mathrm{T}_{4}$ concentrations of these various standards are shown in the right-hand column. The amount of plasma $\mathrm{T}_{4}$ eluted from the dot corresponded to that contained in $1.5 \mu 1$ plasma.

The use of whole blood in the measurement of $T_{4}$ results in an increase in the nonspecific binding of $\mathrm{T}_{4}$ due to some substance, presumably hemoglobin, contained in or on the erythrocytes. This appears as an absolute increase of approximately $10 \%$ in the blank tubes (containing no antibody). When $1.5 \mu \mathrm{l}$ serum (as opposed to whole blood) are added to each tube, the blank is $4-5 \%$. The difference in nonspecific binding is not caused by the presence of

Table 2. Displacement curve using standards prepared from 1/8-inch dots

\begin{tabular}{lcc}
\hline & $\begin{array}{c}\text { \% }\left[{ }^{125}{ }^{2}\right] \mathrm{T}_{4} \text { bound, } \\
\text { mean } \pm \mathrm{SD}\end{array}$ & $\begin{array}{c}\text { Plasma } \mathrm{T}_{4}, \\
\mu \mathrm{g} / 100 \mathrm{ml}\end{array}$ \\
\hline 22 & $68 \pm 2$ & 1.5 \\
80 & $53 \pm 1$ & 5.3 \\
132 & $45 \pm 2$ & 8.8 \\
184 & $40 \pm 1$ & 12.3 \\
236 & $36 \pm 1$ & 15.7 \\
283 & $35 \pm 1$ & 18.9 \\
Blank (no antibody) & $14 \pm 1$ & \\
\hline
\end{tabular}

Table 1. Quantities of blood and $T_{4}$ extraction using $1 / 8$-inch dots

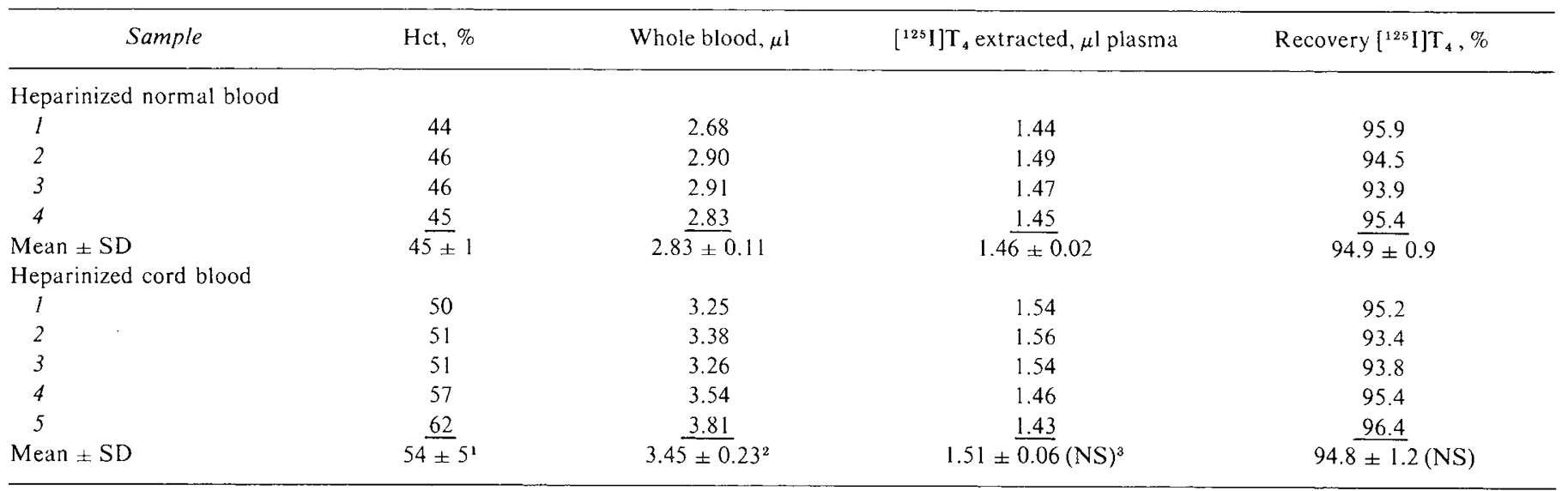

${ }^{1} P<0.025$ for significance of difference between heparinized normal and cord blood by unpaired $t$ test.

${ }^{2} P<0.005$.

${ }^{3}$ Not significant. 
the paper dot per se since removing the dot before separation of bound and free $\mathrm{T}_{4}$ has no effect on the blank and addition of blank paper dots plus serum is also without effect. The percent bound figures presented in Table 2 have not been corrected for nonspecific binding, but this is not different whether the dots are obtained from adults or neonates, nor does it differ from sample to sample.

\section{INTRA- AND INTERASSAY VARIATION}

In Table 3 is shown the coefficient of variation within and between assays. The coefficient of variation is $7-10 \%$ both within and between assays and is similar to the coefficient of variation of $8 \%$ in $\mathrm{T}_{4}$ immunoassays using serum or plasma (5). Analysis of heparinized cord blood $\mathrm{T}_{4}$ concentrations using the dots agreed well with the predicted value determined by $T_{4}$ immunoassay of an aliquot of plasma. In Table 4 are presented data from a systematic study of the correlation between $\mathrm{T}_{4}$ concentrations determined directly from plasma with the calculated value based on the $\operatorname{dot} \mathrm{T}_{4}$. Plasma and dried capillary blood (from a fingerstick) were obtained simultaneously from normal adults or from patients with thyroid disease. The plasma $T_{4}$ was computed from the dot $T_{4}$ content $(C)$ and also measured directly in plasma by radioimmunoassay (M) (5). In 24 samples, from subjects with a broad range of plasma $\mathrm{T}_{4}$ concentrations, there is an excellent correlation between the results obtained by the two techniques. The mean difference of $0.4 \mu \mathrm{g} T_{4} / 100 \mathrm{ml}$ between the measured and calculated values suggests that there is a tendency to underestimate the $T_{4}$ value using fingerstick specimens, but the difference is small. It can be seen that the estimates of $T_{4}$ in patients with hypothyroidism are clearly lower than results obtained from euthyroid and hyperthyroid subjects.

\section{RESULTS OBTAINED TO DATE IN SAMPLES FROM NEONATES}

The mean $\mathrm{T}_{4}$ in 983 neonates is $189 \pm 48 \mathrm{pg}$ of $\mathrm{T}_{4} /$ dot (mean \pm SD). However, $7 \%$ of the values are greater than $283 \mathrm{pg}$ although they were entered as such in the calculation. The estimated plasma $\mathrm{T}_{4}$, assuming $1.5 \mu \mathrm{l}$ plasma equivalent $/ \mathrm{dot}$ is $12.6 \mu \mathrm{g} / 100 \mathrm{ml}$. The standard deviation corresponds to $3.2 \mu \mathrm{g} \mathrm{T}_{4} / 100 \mathrm{ml}$ and thus $2 \mathrm{SD}$ below the mean would be equivalent to a plasma $\mathrm{T}_{4}$ concentration of $6.2 \mu \mathrm{g} \mathrm{T}_{4} / 100 \mathrm{ml}(93 \mathrm{pg} / \mathrm{dot})$. In these first approximately 1,000 samples duplicate analyses have been carried out with excellent agreement. Specimens in which at least one value was less than 93 pg have been repeated and the results of both assays on these specimens are presented in Table 5. The results are grouped based on initial individual and final mean $\mathrm{T}_{4}$ results which were concordant and both less than $93 \mathrm{pg} / \mathrm{dot}$. Of those, seven had low values on repeat testing, although subject $A_{7}$ had a single high value in the second assay. It is of interest that infants $A_{3}, A_{5}$, and $A_{7}$ were all premature. The other four infants on repeated testing proved to have results that were $>93 \mathrm{pg}$. In the case of the 14 infants whose initial results were discrepant, that is, one value above and one value below $93 \mathrm{pg} / \mathrm{dot} 2$ were found to be persistently below $93 \mathrm{pg}$ on repeat testing whereas 11 had mean $\mathrm{T}_{4}$ values on subsequent testing which placed them within $2 \mathrm{SD}$ of the mean. One subject, $E_{1}$, had persistently discrepant results and

Table 3. Intra- and interassay variation

\begin{tabular}{lccc}
\hline Blood sample & $n$ & $\mathrm{pg} /$ dot (mean $\pm \mathrm{SD})$ & $\mathrm{CV},(\%)^{1}$ \\
\hline Intra-assay & & & \\
$\quad$ Cord 1 & 9 & $150 \pm 11$ & 7.3 \\
$\quad$ Cord 2 & 9 & $175 \pm 19$ & 9.2 \\
$\quad$ Cord 3 & 9 & $186 \pm 15$ & 8.0 \\
Interassay, & & $175 \pm 15$ & 8.6 \\
$\quad$ Normal & 11 & \\
\hline
\end{tabular}

${ }^{2}$ Coefficient of variation, $\mathrm{SD} /$ mean.
Table 4. Recovery of thyroxine using dried capillary blood obtained by fingerstick from adults ${ }^{1}$

\begin{tabular}{|c|c|c|c|c|}
\hline \multirow[b]{2}{*}{ Sample } & \multicolumn{2}{|c|}{ Thyroxine } & \multirow[b]{2}{*}{$\begin{array}{l}\text { Measured } \\
\text { plasma } \mathrm{T}_{4}, \\
\mu \mathrm{g} / 100 \mathrm{ml} \\
\text { (M) }\end{array}$} & \multirow[b]{2}{*}{$\begin{array}{c}\Delta \mathrm{M}-\mathrm{C} \\
\mu \mathrm{g} / 100 \mathrm{ml}\end{array}$} \\
\hline & $\mathrm{pg} / \mathrm{dot}$ & $\begin{array}{l}\text { Calculated }{ }^{2} \\
{\text { plasma } \mathrm{T}_{4} \text {, }} \mathrm{g} / 100 \mathrm{ml} \\
\text { (C) }\end{array}$ & & \\
\hline$I$ & $<22$ & $<1.5$ & $<1.0$ & 0 \\
\hline 2 & $<22$ & $<1.5$ & $<1.0$ & 0 \\
\hline 3 & $<22$ & $<1.5$ & $<1.0$ & 0 \\
\hline 4 & $<22$ & $<1.5$ & $<1.0$ & 0 \\
\hline 5 & 38 & 2.5 & 2.2 & -0.3 \\
\hline 6 & 47 & 3.1 & 4.8 & +1.7 \\
\hline 7 & 60 & 4.0 & 4.4 & +0.4 \\
\hline 8 & 70 & 4.7 & 4.6 & -0.1 \\
\hline 9 & 73 & 4.9 & 5.8 & +0.9 \\
\hline 10 & 78 & 5.2 & 4.5 & -0.7 \\
\hline 11 & 84 & 5.0 & 5.0 & +0.9 \\
\hline 12 & 86 & 5.7 & 5.8 & +0.1 \\
\hline 13 & 120 & 8.0 & 8.6 & +0.6 \\
\hline 14 & 130 & 8.6 & 8.9 & +0.3 \\
\hline 15 & 133 & 8.9 & 8.1 & -0.8 \\
\hline 16 & 134 & 8.9 & 7.8 & -1.1 \\
\hline 17 & 140 & 9.3 & 9.1 & -0.2 \\
\hline 18 & 148 & 9.9 & 10.1 & +0.2 \\
\hline 91 & 162 & 10.8 & 11.6 & +0.8 \\
\hline 20 & 170 & 11.3 & 10.8 & -0.5 \\
\hline 21 & 172 & 11.4 & 10.2 & -1.2 \\
\hline 22 & 200 & 13.3 & 15.6 & +2.3 \\
\hline 23 & 232 & 15.5 & 19.1 & $\begin{array}{r}+3.6 \\
+\end{array}$ \\
\hline 24 & 265 & 17.6 & 19.1 & +1.5 \\
\hline
\end{tabular}

${ }^{1}$ Mean $\pm \mathrm{SEM}$ of $\mathrm{M}-\mathrm{C}=+0.4 \pm 0.2 \mu \mathrm{g} \mathrm{T}_{4} / 100 \mathrm{ml}$.

${ }^{2}$ Assuming $\mathrm{T}_{4}$ equivalent to $1.5 \mu \mathrm{l}$ plasma.

although the mean $T_{4}$ was $>93 \mathrm{pg} / \mathrm{dot}$, no reason for the discrepancy was apparent. In the last column of the table are shown cord TSH values in these infants measured in a parallel screening program (4). Despite $\mathrm{T}_{4}$ values which are less than 93 $\mathrm{pg} / \mathrm{dot}$ in nine subjects (groups $A$ and $C$ ) no TSH values were elevated. In addition, during the period of time covered by these assays, no infants with suspected congenital primary hypothyroidism have been recognized using the cord serum TSH screening procedure. We have not observed any $T_{4}$ values which were lower than $3 \mathrm{SD}$ below the mean $(<45 \mathrm{pg} / \mathrm{dot})$.

\section{DISCUSSION}

The $T_{4}$ method described above is rapid, sensitive, and reproducible. The features which are of interest with regard to a screening program are first, the use of $a^{1 / 8}$-inch dot which permits synthesis of this test with current automated methods available for processing filter paper specimens. Second, the smaller quantities of blood required allow frequent repetition of suspicious values. In addition, we have experienced a considerable variation in the completeness of filling of the circles. A $1 / 8$-inch dot eliminates the necessity for prior extraction of $T_{4}$ from the filter paper, thus avoiding a time-consuming step in the procedure.

The mean plasma $T_{4}$ concentration calculated from the dot $T_{4}$, $12.6 \mu \mathrm{g} / 100 \mathrm{ml}$, is lower than the value of $17.2 \mu \mathrm{g} / 100 \mathrm{ml}$ which we obtained from capillary plasma in 23 infants aged 3 days (1). Some of this difference could be a result of the truncation of the extreme upper range since about $7 \%$ of the values were $283 \mathrm{pg}$. Although the volume of plasma per dot is more constant than the volume of whole blood, published data from other laboratories are available only for the latter. A comparison of the computed $T_{4}$ concentrations using this data are presented in Table 6 . The results of 
Table 5. Evaluation of neonatal samples where one or both initial results were $<93 \mathrm{pg} / \mathrm{dot}^{1}$

\begin{tabular}{|c|c|c|c|c|c|c|c|c|c|c|}
\hline \multirow[b]{3}{*}{ Category and subject } & \multicolumn{9}{|c|}{$\mathbf{T}_{4} \mathrm{pg} / \mathrm{dot}$} & \multirow{3}{*}{$\begin{array}{c}\text { Cord TSH, } \\
\mu \mathrm{U} / \mathrm{ml}^{2}\end{array}$} \\
\hline & \multicolumn{3}{|c|}{ Assay 1} & \multicolumn{3}{|c|}{ Assay 2} & \multicolumn{3}{|c|}{ Assay 3} & \\
\hline & 1 & 2 & Mean & 1 & 2 & Mean & 1 & 2 & Mean & \\
\hline \multicolumn{11}{|l|}{$\begin{array}{l}\text { A. Initial and final } \\
\text { value }<93 \mathrm{pg}\end{array}$} \\
\hline 1 & 91 & & 91 & 50 & 45 & 48 & & & & 11 \\
\hline 2 & 61 & 82 & 72 & 95 & 3 & 95 & & & & 9 \\
\hline 3 & 60 & 90 & 75 & 70 & 50 & 60 & & & & 18 \\
\hline 4 & 85 & 95 & 90 & 80 & 70 & 75 & & & & 17 \\
\hline 5 & 75 & 85 & 80 & 45 & 55 & 50 & & & & 25 \\
\hline 6 & 80 & 88 & 84 & 95 & 105 & 100 & 75 & 85 & 80 & 11 \\
\hline 7 & 65 & 70 & 68 & 205 & 70 & 138 & 70 & 3 & 70 & 23 \\
\hline \multicolumn{11}{|l|}{$\begin{array}{r}\text { B. Initial values } \\
\quad<93 \mathrm{pg} \text { : final } \\
\text { value }>93 \mathrm{pg}\end{array}$} \\
\hline 1 & 49 & 48 & 49 & 70 & 120 & 95 & 170 & 100 & 135 & 53 \\
\hline 2 & 84 & 78 & 81 & 105 & 110 & 108 & 115 & 105 & 110 & \\
\hline 3 & 77 & 86 & 82 & 115 & 115 & 115 & 110 & 125 & 118 & \\
\hline 4 & 75 & 80 & 78 & 90 & 100 & 95 & 105 & 105 & 105 & 3 \\
\hline \multicolumn{11}{|l|}{$\begin{array}{l}\text { C. Initial values } \\
\text { discrepant; final } \\
\text { value }<93\end{array}$} \\
\hline 1 & 95 & 35 & 65 & 55 & 70 & 63 & 80 & 95 & 88 & 18 \\
\hline 2 & 115 & 75 & 95 & 65 & 75 & 70 & 75 & 65 & 70 & 29 \\
\hline \multicolumn{11}{|l|}{$\begin{array}{l}\text { D. Initial values } \\
\begin{array}{l}\text { discrepant; final } \\
\text { value }>93\end{array}\end{array}$} \\
\hline 1 & 86 & 120 & 103 & 100 & 85 & 93 & & & & \\
\hline 2 & 144 & 39 & 92 & 90 & 160 & 125 & & & & \\
\hline 3 & 125 & 82 & 104 & 75 & 105 & 90 & & & & \\
\hline 4 & 149 & 82 & 116 & 80 & 110 & 95 & & & & \\
\hline 5 & 143 & 83 & 113 & 130 & 80 & 105 & & & & \\
\hline 6 & 101 & 72 & 87 & 125 & 170 & 148 & & & & \\
\hline 7 & 143 & 82 & 112 & 115 & 55 & 85 & 85 & 115 & 95 & 18 \\
\hline 8 & 60 & $>283$ & $>60$ & 255 & $>283$ & $>255$ & & & & \\
\hline 9 & 87 & 152 & 120 & 150 & 85 & 118 & & & & \\
\hline 10 & 99 & 79 & 89 & 150 & 150 & 150 & & & & \\
\hline 11 & 75 & 110 & 92 & 125 & 140 & 133 & 155 & 105 & 130 & \\
\hline \multicolumn{11}{|l|}{$\begin{array}{l}\text { E. Initial values } \\
\text { discrepant; final } \\
\text { values discrepant }\end{array}$} \\
\hline l & 81 & 206 & 144 & 60 & 125 & 93 & 150 & 40 & $95^{3}$ & \\
\hline
\end{tabular}

${ }^{1} \mathrm{TSH}$ : thyroid-stimulating hormone.

${ }^{2}$ By Dr. T. P. Foley, Jr.; normals $<2.5-60 \mu \mathrm{U} / \mathrm{ml}$.

${ }^{3}$ Quantity not sufficient for further repetition.

Table 6. Comparison of whole blood $T_{4}$ concentrations determined from dried filter paper spots in various laboratories

\begin{tabular}{|c|c|c|c|c|c|c|}
\hline Laboratory & $n$ & $\begin{array}{l}\text { dot diameter, } \\
\text { inches }\end{array}$ & $\begin{array}{c}\mathrm{T}_{4} / \mathrm{sample} \\
\mathrm{pg}\end{array}$ & $\begin{array}{l}\text { Whole blood/ } \\
\text { sample, } \mu \mathrm{l}\end{array}$ & Recovery, \% & $\begin{array}{c}\text { Whole blood } \mathrm{T}_{4}, \\
\mu \mathrm{g} / 100 \mathrm{ml}\end{array}$ \\
\hline $\begin{array}{l}\text { Dussault }(2,3) \\
\text { (Quebec) }\end{array}$ & 36,000 & $1 / 2$ & 1,610 & 40 & 72 & 5.6 \\
\hline $\begin{array}{l}\text { O'Donnell (6) } \\
\text { (Toronto) }\end{array}$ & 1,300 & $1 / 2$ & 2,250 & 31 & 100 & 7.3 \\
\hline Larsen (Pittsburgh) & 983 & $1 / 8$ & 189 & 3.5 & 95 & 5.8 \\
\hline
\end{tabular}

Dussault $(2,3)$ and those reported here are virtually identical, but both are lower than those of O'Donnell et al. (6). The reasons for the latter discrepancy are not clear and may involve differences in the calculated whole blood per dot.

The results of determinations of $\mathrm{T}_{4}$ in dried blood obtained by fingerstick from adults indicates that the method readily identi- fies samples with low plasma $T_{4}$ concentrations. If $T_{4}$ values are low in congenitally hypothyroid children, they should be recognized readily. In addition, the simplicity and ready availability of the method suggests that it might be incorporated into a routine postnatal screening program to identify infants with less severe hypothyroidism. 
The application of this method on a larger scale is currently underway in collaboration with centers receiving larger numbers of samples than we are able to obtain locally. At the present time, a single technician can perform approximately 700 assays/week in duplicate including the determination of each individual result. Based on our results to date, we have adopted the following tentative plan for large scale screening. First, only single samples of each patient will be assayed. With one exception (Table 5, group $C$, subject 2), a cutoff point of 100 pg would not have resulted in misclassification of any of the infants tested. Rather than calculating each individual sample, we are currently determining the actual $\mathrm{T}_{4}$ only in dots with $\mathrm{T}_{4}$ content less than $132 \mathrm{pg}$ (the third standard). We have also eliminated the two higher standards from the standard curve since these levels cannot be accurately quantitated at the antibody dilution optimal for detection of the smaller quantities of $T_{4}$. Specimens with $T_{4}$ values less than 100 will be repeated in duplicate and follow-up data obtained on all subjects with $\mathrm{T}_{4}$ values lower than $2 \mathrm{SD}$ below the mean $(93 \mathrm{pg} / \mathrm{dot})$. Any infants with $\mathrm{T}_{4}$ values less than $3 \mathrm{SD}$ below the mean $(<45 \mathrm{pg} / \mathrm{dot})$ will be recalled immediately for serum $\mathrm{T}_{4}$ and TSH testing. Based on our present experience, this would amount to recall of the patient for a new specimen for $\mathrm{T}_{4}$ determination in about $0.9 \%$ (9/983) of the population. With the present estimates of the frequency of congenital hypothyroidism, only 1 of $80-90$ such infants would prove to be hypothyroid. However, until more precise data is available regarding the $\mathrm{T}_{4}$ concentrations at 3 days in infants with congenital hypothyroidism, it appears advisible to accept this rather high rate of false positives for pilot study purposes.

$\mathrm{T}_{4}$ values were obtained at age $4-6$ weeks for subjects $A_{1}, A_{3}$ and $A_{5}$ and all were normal. Since two of these infants were premature, the low initial values may reflect hypoproteinemia. The normal results of the cord TSH values give us reasonable confidence that none of the remainder of the infants in question have primary hypothyroidism. The more aggressive follow-up approach outlined above is anticipated in conjunction with our studies of larger numbers of patients.

\section{SUMMARY}

A method has been described for immunoassay of $\mathrm{T}_{4}$ using a $1 / 8$-inch dot of filter paper containing dried capillary blood. The dots can be incubated directly in the antibody-tracer-sodium salicylate solution without prior extraction. Recovery to $\mathrm{T}_{4}$ is $95 \%$ and corresponds to the $T_{4}$ contained in $1.5 \mu 1$ plasma. There is an excellent correlation of dot $T_{4}$ values with plasma $T_{4}$ values measured directly in adults with low, normal, and elevated serum $\mathrm{T}_{4}$ concentrations. The mean dot $\mathrm{T}_{4}$ in 983 samples from 3-day-old infants was $189 \pm 48(\mathrm{SD}) \mathrm{pg} \mathrm{T}_{4} /$ dot corresonding to a plasma concentration of $12.6 \pm 3.2 \mu \mathrm{g} \mathrm{T} / 100 \mathrm{ml}$. Although nine neonates were found to have $\operatorname{dot} \mathrm{T}_{4}$ values $<93 \mathrm{pg} / \mathrm{dot}$ (plasma $\mathrm{T}_{4}$ $<6.2 \mu \mathrm{g} / 100 \mathrm{ml}$ ), none had elevated cord TSH values. This appears to be a feasible method for screening the neonate for congenital hypothyroidism and a larger pilot study to determine the appropriate dividing line between the normal and high risk population is currently underway.

\section{REFERENCES AND NOTES}

1. Abuid, J., Klein, A. H., Foley, T. P., Jr., and Larsen, P. R.: Total and free triiodothyronine and thyroxine in early infancy. J. Clin. Endocrinol. Metabol. 39: 263 (1974).

2. Dussault, J. H., Coulombe, P., and Laberge, C.: Preliminary report on a screening program for neonatal hypothyroidism. Abstracts from the Fiftieth Meeting of the American Thyroid Association, Inc., p. T-22 (1974).

3. Dussault, J. H., and Laberge, C.: Dosage De La Thyroxine $\left(\mathrm{T}_{4}\right)$ Par Methode Radio-immunologique Dans L'Eluat De Sang Seche: Nouvelie Methode De Depistage De L'Hypothroidie Neonatale? (L'Union Medicale Du Canada, Tome 102, 1973).

4. Klein, A. H., Augustin, A. V., and Foley, T. P., Jr.: Successful laboratory screening for congenital hypothyroidism. Lancet, ii: 77 (1974).

5. Larsen, P. R., Dockalova, J., Sipula, D., and Wu, F. M.: Immunoassay of thyroxine in unextracted human serum. J. Clin. Endocrinol. Metab., 37: 177 (1973).

6. O'Donnell, J., Frankl, A., and Walfish, P. G.: Screening for neonatal hypothyroidism using dried capillary blood: Observations on sample collection and haematocrit variation. Abstracts from the Fiftieth Meeting of the American Thyroid Association, Inc., T-22 St. Louis, Mo. (1974).

7. Abbott Laboratories, North Chicago, Ill.

8. Sigma Chemical Co., St. Louis, Mo.

9. Fisher Scientific, Pittsburgh, Pa.

10. Pharmacia, Piscataway, N. J.

11. Amersham, Searle, Arlington Heights, Ill.

12. Rohm and Haas, Pennsauken, N. J.

13. Schwarz-Mann, Orangeburg, N. Y.

14. The authors express their appreciation to Dr. T. P. Foley, Jr. for the results of TSH assays and to Ms. K. Bodnar for her excellent secretarial assistance.

15. Dr. P. R. Larsen is Recipient of Career Development Award 70401 from the United States Public Health Service.

16. This report was presented in part at the Symposium on Maternal-Fetal Thyroid Function sponsored by The National Foundation and The Kroc Foundation, November 10-13, 1974

17. This work was supported by Grant 6-74-43 from the National Foundation-March of Dimes and AM14283 from NIAMDD.

18. Requests for reprints should be addressed to: P. Reed Larsen, M.D., Thyroid Unit, Peter Bent Brigham Hospital, 721 Huntington Ave., Boston, Mass. 02115 (USA).

19. Accepted for publication April 2, 1975. 